\title{
Pelatihan Motivasi Kewirausahaan Bisnis Produk Online dan Penyusunan Laporan Keuangan di Perguruan Taman Siswa Semarang
}

\author{
Roymon Panjaitan ${ }^{1}$, Tantiek Sumarlin², Myra Andriana ${ }^{3}$ \\ ${ }^{1,2,3}$ Komputer Akuntansi, Sekolah Tinggi Elektronika dan Komputer, Semarang, Indonesia \\ e-mail :*1roymon_panjaitan@yahoo.com, ${ }^{2}$ tantiksumarlin@yahoo.co.id, \\ ${ }^{3}$ my_andriana@yahoo.com
}

\begin{abstract}
ABSTRAK Pembangunan ekonomi di segala sektor mendorong pelaku usaha untuk meningkatkan pendapatan diluar pekerjaan tetapnya. Mengikuti perkembangan teknologi dan tren pemasaran saat ini, pelatihan kewirausahaan bisnis produk online dan membuat laporan keuangan bagi guru-guru di Perguruan Taman Siswa Semarang sangat diperlukan. Metode yang digunakan dalam pengabdian masyarakat ini adalah dalam bentuk pemaparan alur produk, praktek membuat akun pribadi di blog atau domain, teknik promosi lewat kata-kata dan menghitung langsung biaya terhadap suatu produk dalam laporan keuangan. Hasil yang dicapai, guru-guru dan staf sekolah telah mampu melakukan pemasaran secara online dengan menggunakan media sosial, menghitung biaya modal harga pokok produksi dan menyusun laporan keuangan. Setelah para guru dan staf SMK Taman Siswa melakukan pelatihan ini mereka merasa puas dan termotivasi dengan adanya pelatihan ini untuk menambah pengetahuan tentang jenis-jenis kewirausahaan yang sangat mudah diikuti dan tidak terikat dalam waktu, usia, tempat maupun modal yang diperlukan
\end{abstract}

KATA KUNCI : bisnis produk online, laporan keuangan

ABSTRACT Economic development in all sectors encourages businesses to increase income outside of their permanent jobs. By keeping abreast of current technology and marketing trends, online product business entrepreneurship training and making financial reports for teachers in Semarang's student park colleges. The method used in community service is in the form of product flow exposure, the practice of creating a personal account on a blog or domain, promotion techniques through words and calculating direct costs for a product in financial staments. The results achieved, teachers and school staff have been able to do marketing online using social media, calculate the cost of capital for the cost of production and prepare financial statements. After the SMK Taman Siswa teachers and staff conducted this training they felt satisfied and motivated by this training to increase knowledge about the types of entrepreneurship that were very easy to follow and not bound to time, age, place or capital needed

KEYWORDS : online product business; financial statements

\section{Pendahuluan}

Pertumbuhan ekonomi yang semakin tinggi, mendorong tingkat kebutuhan di segala sektor perekonomian. Hal ini didukung oleh program pemerintah melalui berbagai kebijakan politik dan ekonomi, secara khusus untuk mendorong pelaku ekonomi kreatif mengambil celah dalam berproduksi di beberapa sektor perdagangan produk maupun jasa. Sesuai dengan tujuan 
pembangunan ekonomi yang mandiri dan handal, meningkatkan pendapatan diluar pekerjaan tetap sekarang ini dianggap perlu dilakukan.

Berdasarkan hasil survei yang dilakukan Tim PPM di SMK Taman Siswa Semarang kepada guru dan staf, penulis merumuskan masalah yang dikemukakan oleh mitra bahwa mereka berkeinginan untuk memiliki usaha atau bisnis diluar pekerjaan yang saat ini ditekuni untuk meningkatkan pendapatan pra pensiun dan mengetahui sistem bisnis yang mudah dikelola mulai dari menyusun anggaran modal sampai laporan keungannya. Atas dasar hasil survei tersebut, Tim PPM merasa perlu melakukan pelatihan motivasi kewirausahaan. Dengan menyesuaikan perkembangan teknologi dan tren pemasaran saat ini, Tim PPM memilih kewirausahaan bisnis produk online. Pelatihan kewirausahaan ini juga dilengkapi dengan teknik penyusunan laporan keuangan. Dimana laporan keuangan merupakan hal penting dalam suatu bisnis. Tim PPM mencoba untuk menyajikan teknik penyusunan laporan keuangan yang sederhana, sehingga mudah untuk dipahami.

Dengan merespon kebutuhan dan keinginan guru SMK Taman Siswa Semarang, Tim PPM memilih program Pelatihan Motivasi Kewirausahaan Bisnis Produk Online dan Penyusunan Laporan Keuangan. Tim melakukan pelatihan kewirausahaan bisnis online dan pemaparan contoh konkrit, serta menjelaskan teknik penyusuanan laporan keuangan bertujuan meningkatkan jiwa kewirausahaan untuk menambah penghasilan, memberikan pengetahuan sistem pemasaran produk online dan memahami membuat anggaran biaya harga pokok produksi dan penyusuna laporan keuangannya. Dengan pelatihan ini besar harapan kami dapat memberikan motivasi usaha atau bisnis online yang bisa dilakukan oleh guru dan staf dalam meningkatkan pendapatan maupun mempersiapkan masa purna bakti. Selain bertujuan untuk memenuhi kebutuhan mitra, hasil dari pelatihan ini tentunya dapat mempermudah kebutuhan konsumen dengan cepat dan mudah mendapatkannya, mampu menghitung harga pokok produksi untuk menentukan harga jual sampai dengan membuat laporan keuangan bagi peserta yang akan memulai bisnis produk online dengan aman dan terarah.

\section{Metode}

Metode pembahasan yang diberikan oleh tim dalam tujuan pelatihan ini yaitu dengan memaparkan secara terperinci alur menciptakan suatu produk., memberikan contoh membuat akun pribadi di media sosial atau mendaftar di blog atau domain orang lain yang berbayar, membuat strategi pemasaran dalam bentuk promosi lewat kata - kata dengan gambar disertai promo harga di akun media sosial dan menghitung langsung harga pokok produksi untuk menentukan harga jual dan menjelaskan penyusunan laporan keuangan yang sederhana. Lokasi tempat kegiatan Pelatihan dilakukan di SMK Taman Siswa yang beralamat di Jalan Tuntang No. 3 RT. 1 RW. 6 Citarum Utara, Desa Mlatiharjo, Kelurahan Mlatiharjo, Kecamatan Semarang Timur, Kota Semarang. Waktu Kegiatan dilaksanakan pada tanggal 21 Maret sampai dengan 23 Maret 2019. Teknik dalam pengumpulan data sebagai bahan acuan kebutuhan pengabdian ini adalah tim melakukan wawancara dari 20 guru, 5 
karyawan sekolah. Dari hasil ini kami mengambil kebutuhan yang paling signifikan adalah keinginan mitra untuk memiliki usaha lain selain bekerja di sekolah dan menghitung biaya modal dalam memulai usaha tersebut. Teknik analisa data dengan menggunakan data deskriptif dari kebutuhan mitra dalam mencari solusi di dalam pekerjaan mereka sehari - hari.

\section{Hasil}

Berdasarkan pelatihan kewirausahaan dan penyusuan laporan keuangan yang telah dilakukan, hasilnya adalah :

a. Guru-guru dan staf sekolah telah mampu melakukan pemasaran secara online dengan menggunakan media sosial tidak berbayar untuk awalannya, menghitung harga pokok produksi, dan menyusun laporan keuangan sederhana.

b. Peserta dapat mentransfer pengetahuan terkait bisnis pemasaran online, menghitung biaya modal harga pokok produksi untuk mencapai jumlah laba yang diinginkan, dan menyusun laporan keuangan sederhana kepada orang lain.

Tabel 1. Hasil Data Statisitik Populasi SMA Taman Siswa

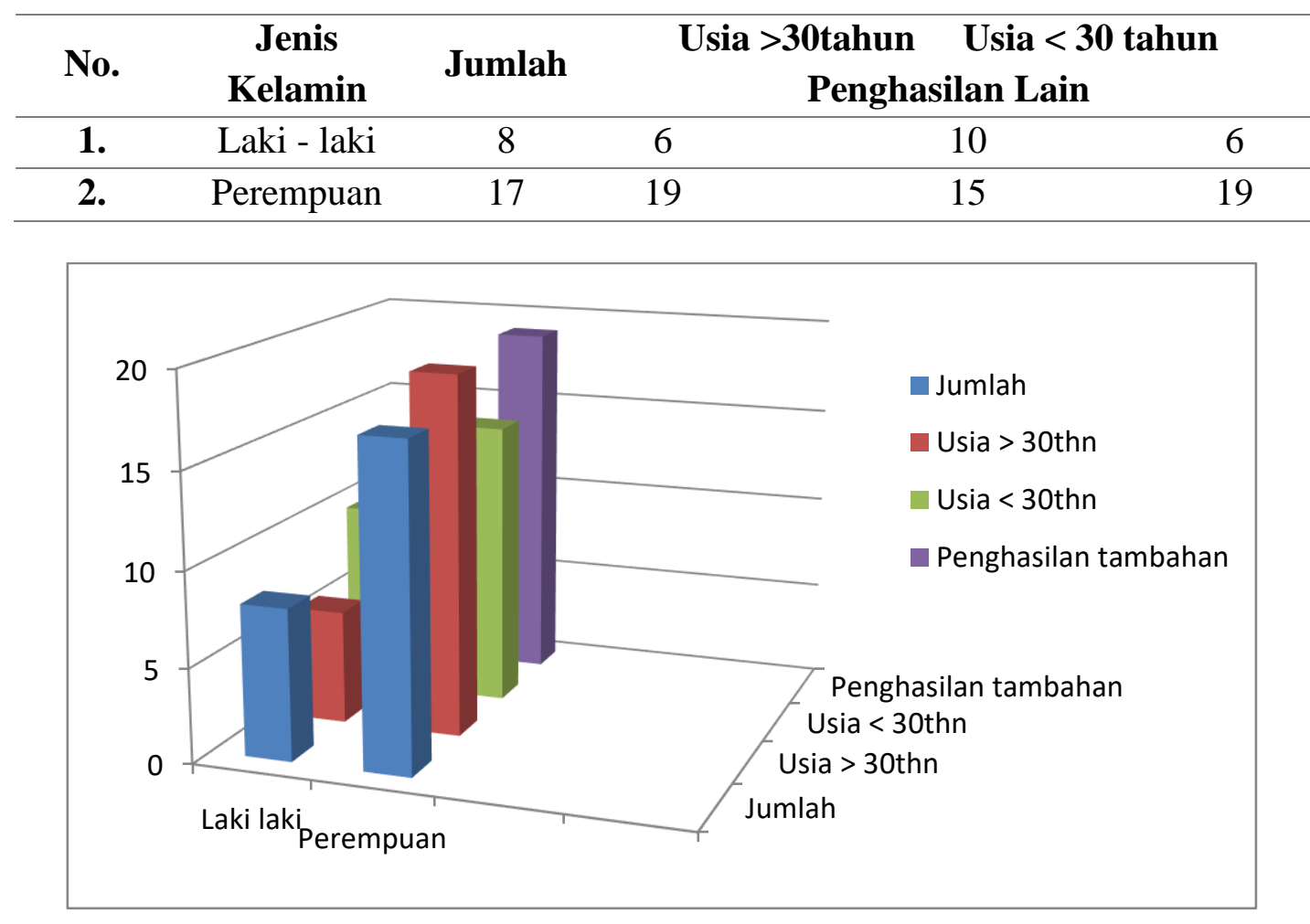

Gambar 2. Grafik Hasil Data Statistik Populasi SMA Taman Siswa 

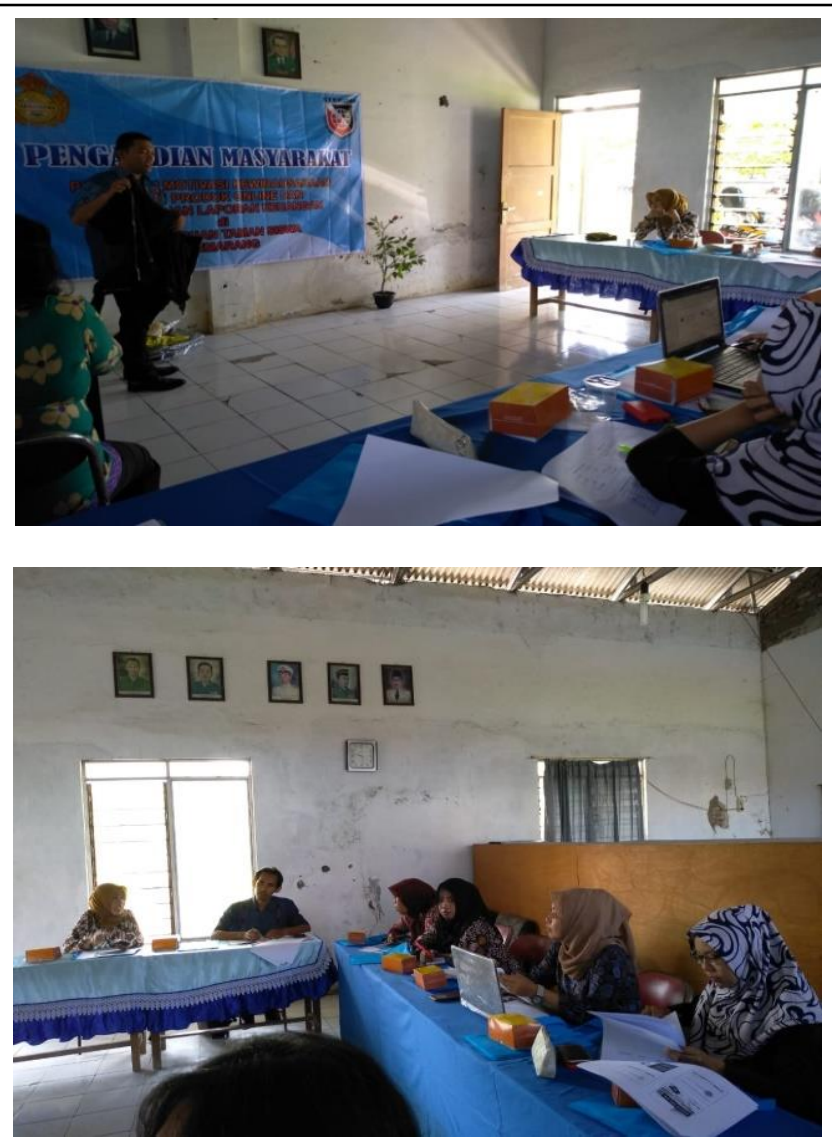

Uraian Foto ke - 1 : Dalam keterangan foto diatas, penulis sekaligus pelaku usaha yang sudah lebih dulu menjalankan usaha ini memaparkan metode alur produksi yang dipakai untuk menciptakan strategi bisnis online dari mulai dari pembelian, pemilihan bahan proses produksi sampai dengan pemaparan sistem pemasaran produksi dengan menggunakan bisnis online di sistem e-commerce yang akan dijual di masyarakat.

Uraian Foto ke - II : Berikut dari foto yang ditampilkan, penulis memberikan contoh hasil barang barang produksi dalam bantu pakaian, celana, tas, dan lainnya yang sudah siap diedarkan atau dijual kepada masyarakat dengan pemesanan secara online dengan penggunaan metode dropshipper atau reseller yang sudah dijelaskan di atas. Barang tersebut sudah tercantum merk dari penjual dan legalitas merknya sudah sah secara hukum dan tidak dapat dipalsukan oleh kompetitor lain.

Dalam gambar di atas pemberi pelatihan dan guru - guru berdiskusi dalam sesi tanya jawab mengenai pengalaman dan hal - hal yang perlu dipersiapkan dalam memulai bisnis online. Peserta antusias dalam berdiskusi karena bisnis ini menurut mereka tergolong mudah hanya saja mereka yang masih bingung menentukan pemilik produk yang baik dalam kualitas pelayanan dan sesuai dengan harapan konsumen. Sebagian besar peserta ingin menjalankan bisnis dropshipper terlebih dahulu karena selain tidak butuh modal dan lebih mudah dikerjakan di sela - sela kesibukan bekerja di sekolah. 

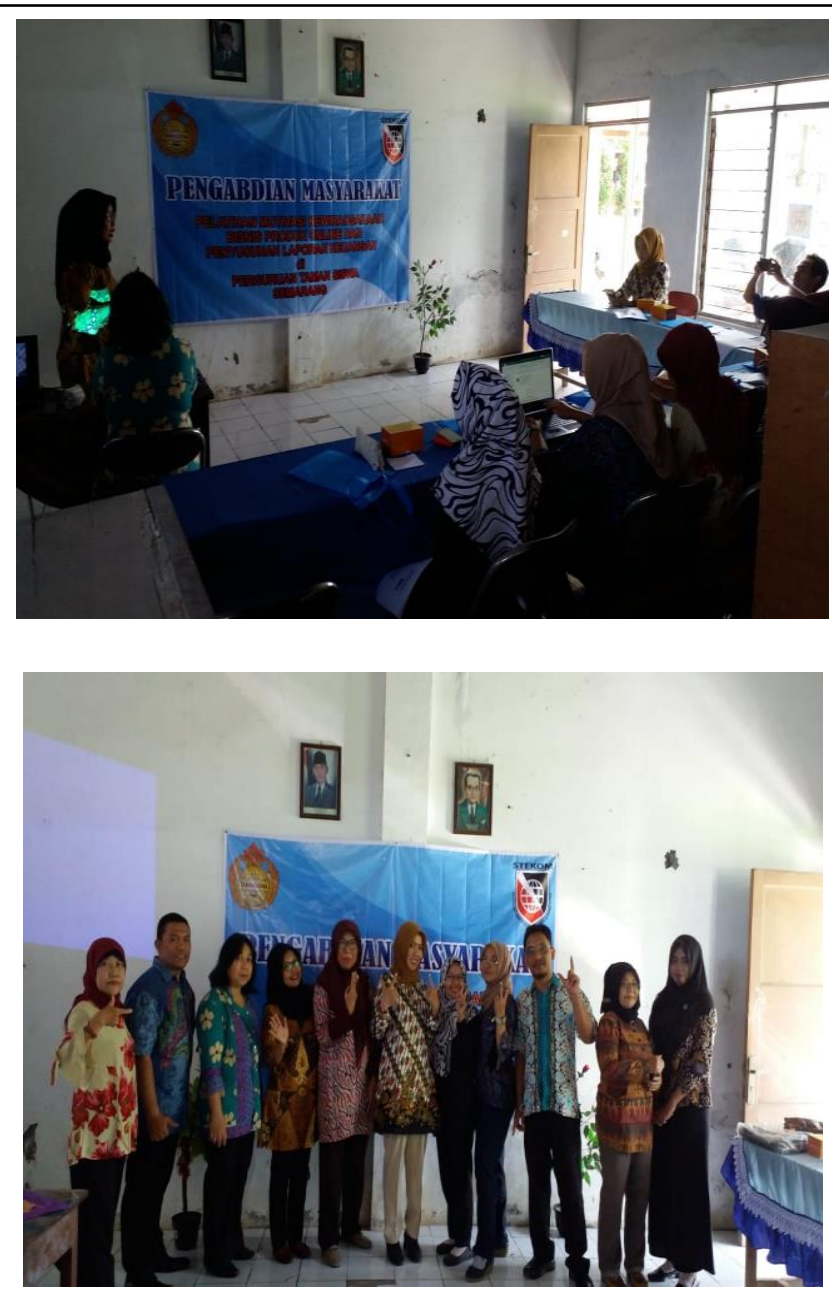

Uraian Foto ke - III : Setelah guru - guru dilatih dalam menciptakan strategi bisnis online, pemberi pelatihan juga memaparkan penyusuanan anggaran modal dalam penyusunan harga pokok produksi yang berguna untuk menyusun anggaran produksi terhadap suatu modal barang mulai dari harga bahan baku sampai dengan harga jual yang dijual online melalui e-commerce. Dalam penyusunan anggaran ini pelaku usaha tentunya diharapkan dapat menyusun Laporan Keuangan yang terdiri dari Laporan Rugi - Laba, Arus Kas dan Neraca sesuai dengan Standar Akuntansi Keuangan UMKM. Selain itu penggunaan software keuangan juga dapat membantu mempercepat pencatatan proses keuangan sampai hasil laporan keuangan. Pelaku usaha tidak hanya dilatih untuk berbisnis transaksi online tetapi pelatih ingin memberikan pelatihan suatu sistem informasi keuangan dalam perencanaan laba yang efisien.

Uraian Foto ke - IV : Berikut foto bersama dari dosen- dosen STEKOM yang diikuti oleh Ibu Kepala Sekolah dan Wakil Kepala Sekolah SMK Taman Siswa beserta perwakilan guru - guru yang hadir dalam pelatihan ini. 

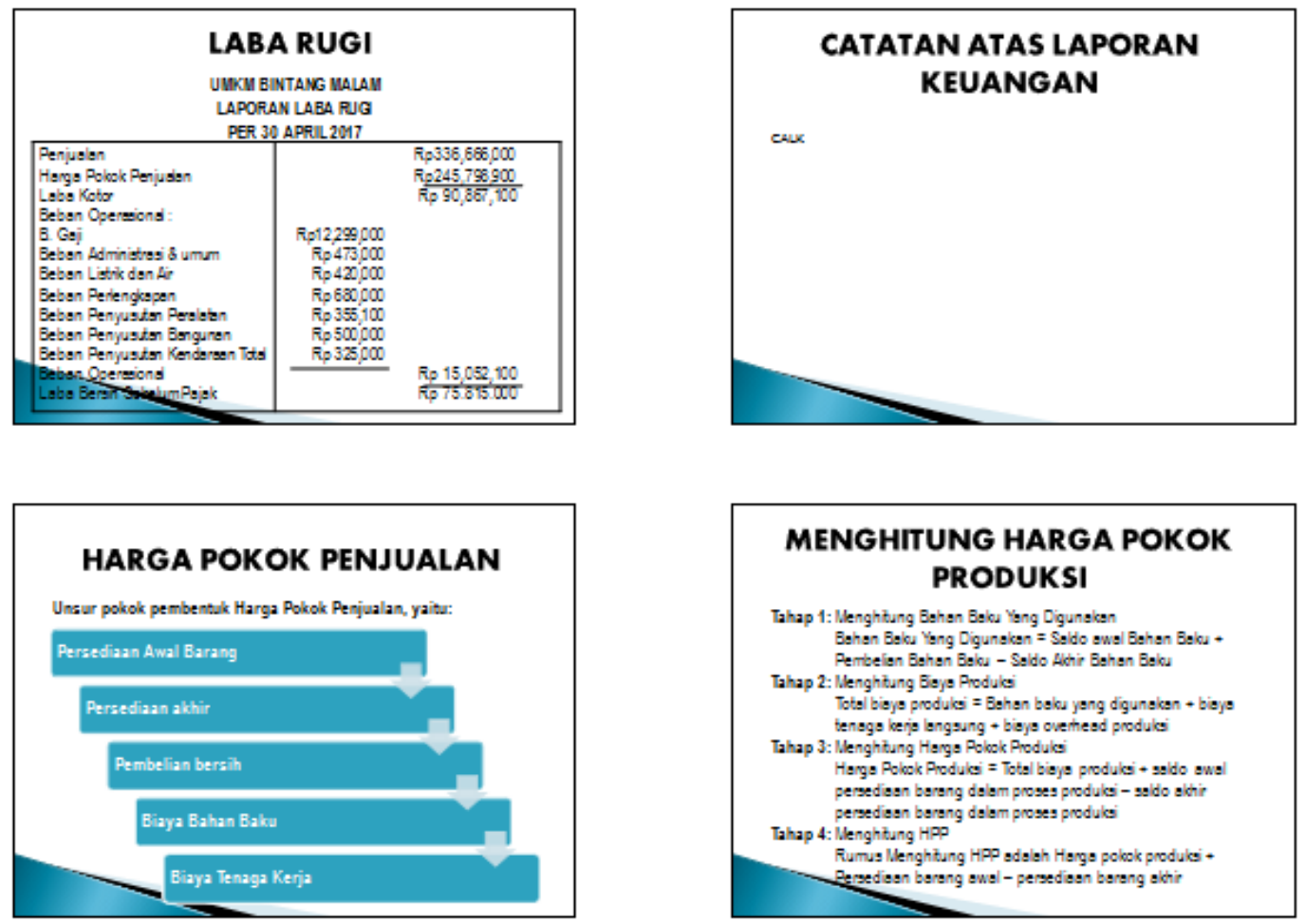

\section{Pembahasan}

Tim pelaksana program pelatihan motivasi kewirausahaan dan penyusunan laporan keuangan bagi guru-guru dan staf SMK Taman Siswa Semarang Yayasan Perguruan Taman Siswa Semarang dilakukan oleh 3 orang pelaksana dari Sekolah Tinggi Elektronika dan Komputer Cabang Ungaran Kabupaten Semarang. Solusi yang dalam acara ini memberikan solusi terhadap kebutuhan para guru beserta staf di lingkungan SMK Taman Siswa Semarang yang telah dirumuskan pada uraian sebelumnya. Beberapa langkah yang diperlukan dalam memulai bisnis online, yaitu menentukan ide, melakukan riset, mengumpulkan konten, cari program afiliasi, membuat blog, situs dengan domain, membeli hosting online situs, membuat promo online, menghitung harga pokok produksi untuk modal awal sampai perhitungan target keuntungan dan menyusun laporan keuangan.

\section{Kesimpulan}

Program pelatihan ini telah berjalan sesuai dengan jadwal yang di tentukan. Peserta yang merupakan guru dan staf SMK Taman Siswa merasa puas dan termotivasi dengan adanya pelatihan ini. Hal tersebut dapat dilihat dari partisipasi kehadiran peserta dan respon pada saat sesi tanya jawab. Guru dan staf yang mengikuti pelatihan merasa membutuhkan pelatihan ini untuk menambah pengetahuan tentang jenis - jenis kewirausahaan yang sangat mudah diikuti dan tidak terikat dalam waktu, usia, tempat maupun modal yang diperlukan. Harapan peserta setelah pelatihan dapat segera menerapkan dalam kegiatan sehari - hari atau mentransfer pengetahuan kepada orang lain. Setelah selesainya program ini, peserta mengharapkan adanya pendampingan langsung dalam memulai usaha dan adanya pelatihan interaktif lainnya dalam peningkatan penggunaan teknologi agar dapat menaikkan kompetensi dalam 
persaingan bisnis. Pelaksanaan program pelatihan sudah sesuai dengan tujuan awal yaitu memotivasi peserta peserta untuk berbisnis online dan menyusun laporan keuangan untuk bisnisnya. Saran program pelatihan selanjutnya sebagai berikut :

a. Perlunya peningkatan kemampuan penguasaan fitur teknologi canggih berbasis smartphone untuk mempercepat bisnis pemasaran.

b. Perlunya pendampingan penggunaan software pemasaran dan keuangan kepada guru dan staf.

c. Perlunya penyuluhan dalam bentuk komunitas online sehingga pelaku bisnis dengan cepat bertukar informasi mengenai strategi dan informasi tren produk.

d. Perlunya pelatihan lebih lanjut terkait dengan penyusunan laporan keuangan untuk meningkatkan pemahaman megenai laporan keuangan.

e. Peningkatan kerjasama perlu dilakukan kembali dalam bentuk materi pengabdian yang lain guna memberikan manfaat pengetahuan kepada masyarakat.

\section{Ucapan terima kasih}

Kami mengucapkan terima kasih kepada Bapak Eka Satria Wibawa, S.Kom., M.Si selaku dosen STMIK Provisi, sebagai sumber informasi kepada tim pelaksana pengabdian di Perguruan Taman Siswa Semarang, Dr. Unang Achlison, S.T., M.Kom selaku Ketua LPPM STEKOM., Rusnawati, S.Pd selaku Kepala Sekolah SMK Taman Siswa Semarang, Wiwik, S.Pd selaku Wakil Kepala Sekolah SMK Taman Siswa Semarang atas selesainya tugas pengabdian masayarakat ini yang telah memberikan dukungan lewat sumbang saran dan ijin untuk melakukan pengabdian ini. Seluruh pengabdian mampu kami selesaikan dengan target kedua belah pihak dengan secara swadaya dan tentunya dapat memberikan terobosan dalam pencapaian target bersama di kemudian hari.

\section{Daftar pustaka}

[1] Panjaitan Roymon, Manajemen Pemasaran.: Soekarno Pressindo, 2018.

[2] Sony Warsono and dkk, Akuntansi UMKM Ternyata Mudah Dipahami dan dipraktekan. Yogyakarta: Asgard Chapter, 2010.

[3] Anonim, Materi Persentasi Bisnis Online. Semarang: STEKOM Semarang, 2019.

[4] Anonim, Materi Penyusunan Laporan Keuangan. Semarang: STEKOM Semarang, 2019. 